\title{
Tantangan Akuntansi Dalam Pengungkapan Corporate Sosial Responsibilities dan Pembangunan Berkelanjutan
}

\author{
Akbar Yusuf \\ Program Studi Akuntansi Fakultas Ekonomi \\ Universitas Muhammadiyah Kupang
}

\begin{abstract}
The purpose of this study to determine the accounting challenges in the disclosure of corporate social responsibilities and sustainable development by using a conceptual study approach. The study shows that the challenges faced in the field of accounting for sustainable development is the complexity and uncertainty of the subject, which began with the absence of a clear definition to be understood about "sustainable development", the accountant should have an important role to determine the sustainability, the inconvenience of the relationship between sustainability and the main purpose of business, practical difficulties are the current accounting system did not facilitate the inclusion of environmental and social factors external to the organization's operations. This study suggests the role of accountants to improve the transparency of business activities, particularly in the areas of social and environmental impacts.
\end{abstract}

Keywords: Corporate Sosial Responsibilities, sustainability of development

\section{Pendahuluan}

Tanggung jawab akuntansi dalam mengungkapkan tanggung jawab sosial dan lingkungan perusahaan, terutama perusahaan multi-nasional, telah mengalami peningkatan signifikan dalam dekade terakhir ini. Namun, di saat yang sama, bukti review empiris dari pengungkapan telah menyimpulkan bahwa corporate sosial responsibility (CSR) sering memperlihatkan, kekurangan utama dalam hal: kelengkapan dan keandalan dari isi substantifnya (Belal, 2002; Adams, 2004) dalam Dey (2007). Pada saat yang sama juga, beberapa peneliti terus mempertahankan kepentingan pragmatis tentang "proyek akuntansi sosial" (Gray, 2002). Dalam perspektif ini, CSR dipandang sebagai mekanisme yang dapat menjadi ramah, daripada memfitnah, yang mempengaruhi akuntansi dapat digunakan untuk memobilisasi perubahan organisasi yang berarti terhadap praktek bisnis yang kurang etis dan tidak berkelanjutan (Dey, 2007). Pandangan Dey ini menunjukkan bahwa akuntansi memiliki posisi strategi untuk memobilisasi informasi sekaligus perubahan dari praktekpraktek bisnis yang kurang etis dan tidak berkelanjutan, sehingga akuntansi harus berperan mendorong perusahaan untuk melakukan aktifitas operasi yang memiliki nilai-nilai etis sekaligus memberikan dampak yang berkelanjutan. Namun, jika peran ini tidak mampu diemban oleh akuntansi, maka kredibilitas pengungkapannya menjadi masalah. Artinya bahwa akuntansi harus benar-benar mengungkapkan informasi secara tepat dan benar. 
Pengungkapan kegiatan sosial dan lingkungan organisasi dalam laporan tahunan menjadi salah satu isu yang muncul baik di kalangan peneliti maupun praktisi bisnis. Iyoha (2010) dalam Ebimobowei (2011) menyatakan bahwa masyarakat membutuhkan laporan akuntansi sosial dalam banyak cara yang sama dengan pasar modal memerlukan informasi keuangan yang disediakan oleh sistem akuntansi keuangan. Pengguna informasi akuntansi sosial membutuhkan data yang memungkinkan mereka untuk menilai apakah entitas bertanggung jawab secara sosial, finansial dan lingkungan. Pandangan ini mendukung Ramanathan(1976) dalam Ebimobowei (2011) yang mengatakan bahwa tujuan dari akuntansi sosial adalah untuk membantu mengevaluasi seberapa baik suatu perusahaan memenuhi kontrak sosial, terutama terkait dampak dari kegiatan suatu perusahaan terhadap masyarakat.

Baik Iyoha maupun Ramanathan telah menakankan wajibnya (mandatory) pengungkapan yang tidak sekedar sebagai pelengkap laporan keuangan, tapi memiliki posisi yang sama dengan laporan keuangan itu sendiri, sebagai bahan evaluasi stakeholder sejauh mana perusahaan telah peduli sebagai wujud tanggung jawab sosialnya, serta mengungkapkan juga dampak dari kegiatannya terhadap masyarakat. Ini menunjukkan bahwa, masa depan atau keberlanjutan suatu perusahaan tidak terlepas dari tanggung jawab sosial perusahaan, karena hasil evaluasi tersebut merupakan pertimbangan stakeholder dalam pengambilan keputusan berkait dengan eksistensi perusahaan.

Laporan Accounting for Sustainability Group yang diselenggarakan oleh HRH The Prince of Wales tahun 2006, menunjukkan bahwa isu-isu akuntansi yang berkelanjutan dan pengambilan keputusan, sebagaimana tercermin dalam munculnya banyaknya literatur yang didedikasikan untuk persoalan ini, dimana kesadaran organisasi yang meningkat tentang pentingnya praktek bisnis berkelanjutan, yang dibuktikan misalnya dengan fakta bahwa pada tahun 2004 sekitar 52\% dari 250 Global Fortune yang menghasilkan laporan lingkungan atau keberlanjutan secara sukarela. Ada juga pemahaman yang berkembang bahwa akuntan memiliki peran penting untuk menentukan, yang ditunjukkan oleh pekerjaan yang sedang dilakukan oleh badan akuntansi yang mengarah ke profesi yang terlibat dalam isu-isu keberlanjutan. Namun, belum adanya kesepakatan di antara akademisi tentang arah ke depan, dan masih ada sejumlah hambatan untuk keberhasilan integrasi keberlanjutan ke dalam proses organisasi. Secara kontras, Gray (2001) melihat bahwa akuntansi sosial dan lingkungan masih tertanam dalam konvensi, kebiasaan dan peraturan organisasi, dimana menurut Gray bahwa akuntansi sosial dan lingkungan harus tidak lagi tunduk pada kehendak politik atau diserahkan pada tindakan sukarela perusahaan.

61| Page 
Dari berbagai pandangan di atas, bagaimana pun perusahaan telah memberikan dampak akibat kegiatan usahanya baik secara sosial maupun lingkungan, sehingga perusahaan tidak hanya semata-mata mengejar tujuan profitnya, tapi juga harus memiliki tanggung jawab sosial dan lingkungan. Sebagaimana Elkington (1998) yang dikutip Burhany dengan pendekatan triple bottom line, yang menyatakan bahwa agar dapat bertahan dalam jangka panjang (sustainable) suatu organisasi (perusahaan) harus aman secara finansial, harus mengeliminasi atau paling tidak meminimalkan dampak negatif terhadap lingkungan, dan harus bertindak sesuai dengan harapan masyarakat. Ketiga elemen triple bottom line tersebut dikenal juga dengan 3P yaitu Profit, Planet, People atau ekonomi (economic), lingkungan hidup (environmental), sosial (sosial).

Untuk membahas lebih jauh tentang tantangan akuntansi, pengungkapan CSR dan sustainability development, maka fokus paper ini, akan mengeksplorasi tantangan akuntansi dalam pengungkapan CSR (sosial dan lingkungan). Sehingga pada bagian-bagian berikut dari paper ini akan membahas: Konsep akuntansi sosial dan lingkungan, alasan pengungkapan sosial dan lingkungan, determinan pengungkapan sosial dan lingkungan, tantangan akuntansi dalam pengungkapan sosial dan lingkungan untuk pembangunan berkelanjutan, akuntansi untuk keberlanjutan pembangunan, dan diakhiri dengan kesimpulan.

\section{Konsep Akuntansi Sosial dan Lingkungan}

\subsection{Akuntansi sosial}

Banyak ahli telah memberikan defenisi tentang akuntansi sosial, diantaranya adalah, Ebimobowei (2011), bahwa Akuntansi sosial adalah berkaitan dengan pengembangan sistem pengukuran untuk memantau kinerja sosial. Sementara Gray (2000) dalam Ebimobowei (2011) berpendapat bahwa akuntansi sosial sebagai "penyiapan dan publikasi account organisasi tentang sosial, lingkungan, interaksi pemangku kepentingan karyawan, masyarakat, pelanggan dan kegiatan lainnya, serta sebagai konsekuensi dari interaksi dan kegiatannya". Kemudian Alexander dan Britton(2000) dalam Ebimobowei (2011), bahwa akuntansi sosial sebagai pelaporan biaya-biaya dan manfaat yang dapat atau tidak dapat diukur dalam bentuk uang, yang timbul dari kegiatan ekonomi dan secara substansial ditanggung atau diterima oleh masyarakat dalam kelompok besar atau tertentu yang tidak memegang hubungan langsung dengan entitas pelapor. Sementara Belkaoui (1993) dalam Burhany melihat secara spesifik dengan mendefinisikan akuntansi sosial sebagai: "proses pengurutan, pengukuran, dan pengungkapan pengaruh yang kuat dari pertukaran antar suatu perusahaan dan lingkungan sosialnya." 
Dari berbagai pendapat tentang defenisi akuntansi sosial di atas, dapat disimpulkan bahwa akuntansi sosial merupakan penyiapan, pengukuran dan pengungkapan tentang biaya dan manfaat yang timbul sebagai konsekuensi dari interaksi dan kegiatan sosial perusahaan kepada berbagai stakeholder. Di sini, nampak bahwa ruang lingkup akuntansi sosial memiliki area yang sangat luas, sehingga Estes (1976) dalam Burhany, memberikan cakupan sosial yang meliputi, lingkungan (environment), masyarakat (community), dan pekerja (employee).

\subsection{Akuntansi Lingkungan}

Schalteger et al. (1996) dalam Lako (2011 hal. 120) mendefenisikan akuntansi lingkungan sebagai suatu sub area dalam akuntansi yang berhubungan dengan aktifitas, metode dan sistem pencatatan, analisis, dan pelaporan informasi lingkungan terkait dengan dampak-dampak keuangan dan ekologis dari suatu sistem ekonomi korporasi.

Sementara ruang lingkup akuntansi lingkungan oleh Gray dan Bebbington (2001) yang dikutip Lako (2011 hal. 120) mencakup: 1) pertanggungjawaban kewajiban dan resiko kontinjen; 2) pertanggungjawaban atas revaluasi asset dan proyeksi modal; 3) analisis biaya dalam area-area penting seperti energy, limbah dan proteksi lingkungan; 4) pengembangan system akuntansi dan system informasi baru yang melingkupi semua area performa lingkungan; 5) menilai cost dan benefits dari program-program lingkungan; 6) pengembangan teknik-teknik akuntansi yang dapat mengungkapkan nilai asset, kewajiban dan equitas dalam terminologi ekologi.

Gambaran di atas menunjukkan bahwa hakikat akuntansi lingkungan atau CSR sebagai suatu proses pengukuran, pencatatan, pelaporan dan pengungkapan informasi yang terkait dengan dampak sosial dan lingkungan dari operasi perusahaan kepada para stakeholders.

\section{Alasan Pengungkapan Sosial dan Lingkungan (PSL)}

Berdasarkan review dan sintesis yang dilakukan oleh Deegan (2002) dalam Chariri (2008) bahwa alasan pengungkapan sosial dan lingkungan antara lain:

a. keinginan untuk mematuhi persyaratan yang ada dalam undang-undang. Namun Deegan (2000), alasan ini sebenarnya bukanlah alasan utama yang ditemukan di berbagai Negara karena ternyata tidak banyak aturan yang meminta perusahaan mengungkapkan informasi sosial dan lingkungan.

b. Pertimbangan rasionalitas ekonomi (economic rationality). Atas dasar alasan ini, praktik PSL memberikan keuntungan bisnis karena perusahaan melakukan "hal yang benar" dan alasan ini mungkin dipandang sebagai motivasi utama (Friedmann 1962).

63| Page 
c. Keyakinan dalam proses akuntabilitas untuk melaporkan. Artinya, manajer berkeyakinan bahwa orang memiliki hak yang tidak dapat dihindari untuk memperoleh informasi yang memuaskan (Hasan 1998; Donaldson dan Preston 1995; Freeman dan Reed 1983) tidak peduli dengan cost yang diperlukan untuk menyajikan informasi tersebut.

d. Keinginan untuk mematuhi persyaratan peminjaman. Lembaga pemberi pinjaman—sebagai bagian dari kebijakan manajemen resiko mereka—cenderung menghendaki peminjam untuk secara periodic memberikan berbagai item informasi tentang criteria dan kebiajakn sosial dan lingkungannya.

e. Untuk mematuhi harapan masyarakat, yang didasarkan pada pandangan bahwa kepatuhan terhadap "ijin yang diberikan masyarakat untuk beroperasi" (atau "kontrak sosial") tergantung pada penyediaan informasi berkaitan dengan kinerja sosial dan lingkungan (Deegan 2002).

f. Sebagai konsekuensi dari ancaman terhadap legitimasi perusahaan. Misalnya, pelaporan mungkin dipandang sebagai respon atas pemberitaan media yang bersifat negative, kejadian sosial atau dampak lingkungan tertentu atau barangkali sebagai akibat dari rating yang jelek yang diberikan oleh lembaga pemberi peringkat perusahaan (Deegan et al. 2000; 2002; Patten 1992).

g. Untuk memanage kelompok stakeholder tertentu yang powerfull (Ullman 1985; Roberts 1992; Evan dan Freeman 1988; Neu et al. 1998).

h. Untuk menarik dana investasi. Di beberapa Negara, "ethical investment funds" merupakan bagian penting dari pasar modal yang semakin meningkat peranannya, misalnya the Dow Jones Sustainability Group Index. Pihak yang bertanggung jawab dalam merankin organisasi tertentu untuk tujuan analisis portofolio menggunakan informasi dari sejumlah sumber termasuk informasi yang dikeluarkan oleh organisasi tersebut.

i. Untuk mematuhi persyaratan industri atau code of conduct tertentu. Misalnya, di Australiaindustri pertambangan memiliki Code for Environmental Management, jadi ada tekanan tertentu untuk mematuhi aturan tersebut. Aturan tersebut dapat mempengaruhi persyaratan pelaporan (Deegan dan Blomquist, 2001).

j. Untuk memenangkan pelaporan tertentu. Ada berbagai penghargaan yang diberikan oleh beberapa Negara kepada perusahaan yang melaporkan kegiatannya termasuk kegiatan berkaitan dengan aspek sosial dan dampak lingkungan. Contohnya penghargaan yang diberikan oleh the Association of Chartered Certified Accountants. Banyak organisasi yang berusaha memenangkan penghargaan tersebut dengan harapan memperbaiki image positive perusahaan.

64 | Page 
Memenangkan perusahaan memiliki implikasi positif terhadap reputasi perusahaan di mata stakeholdernya (Deegan dan Carol 1993).

\section{Determinan Pengungkapan Sosial dan Lingkungan}

Banyak penelitian yang mencoba mengungkapkan faktor-faktor yang mempengaruhi luas/kualitas/kuantitas pengungkapan sosial dan lingkungan. Chariri (2008) menggunakan contract sosial theory untuk melakukan kritik sosial atas penggunaan teori yang melandasi berbagai penelitian tentang sosial dan lingkungan telah mensintesiskan berbagai faktor yang mempengaruhi luas/kualitas/kuantitas pengungkapan sosial dan lingkungan antara lain:

a. Andrew et al. (1989) melakukan penelitian tentang praktek akuntansi di Malaysia dan Singapura. Tema sosial disclosure yang digunakan antara lain human resources, ketertiban masyarakat, lingkungan dan produk. Hasil penelitiannya menunjukkan bahwa perusahaan besar cenderung mengungkapkan aktifitas sosial lebih banyak dibandingkan perusahaan kecil. Namun demikian luas pengungkapan tersebut jauh lebih rendah dibandingkan UK dan US.

b. Guthrie dan Parker (1989) melakukan analisis historis terhadap praktek pengungkapan sosial pada Broken Hill Proprietary Company Ltd (BHP) di Australia selama 100 tahun sejak 1885. Penelitian dilakukan dengan menggunakan teori legitimasi. Penelitian tersebut menunjukkan bahwa praktek pengungkapan sosial pada era tersebut sangat bervariasi. Selama periode tersebut ada kecenderungan bahwa perusahaan melakukan pengungkapan untuk tujuan memperoleh legitimasi sebagai respon atas tekanan public.

c. Patten (1991) berusaha menguji pengaruh public pressure dan profitabilitas terhadap pengungkapan sosial 156 perusahaan yang terdapat pada Fortune 500 tahun 1985. Dengan menggunakan teori stakeholder, Patten menunjukkan bahwa size dan industri berhubungan dengan luas pengungkapan sosial namun demikian profitabilitas tidak berpengaruh terhadap pengungkapan tersebut. Hasil ini digunakan untuk sebagai dasar untuk membuktikan bahwa pengungkapan sosial lebih berkaitan dengan tekanan public.

d. Penelitian berikutnya oleh Patten (1992) berusaha meneliti isu lingkungan pada industri pertambangan setelah terjadi kasus kebocoran minyak Exxon Valdes Alaska. Hasil penelitian menunjukkan bahwa luas pengungkapan lingkungan, baik bersifat keuangan maupun non keuangan cenederung meningkat sejak kasus kebocoran tersebut. Size dan kepemilikan merupakan factor yang secara signifikan mempengaruhi pengungkapan tersebut. Patten (1992) menyimpulkan bahwa ancaman terhadap legitimasi perusahaan merupakan factor pendorong perlunya pengungkapan lingkungan.

65| Page 
e. Hackston dan Milne (1996) meneliti pengungkapan sosial dalam annual report 50 perusahaan terbesar di New Zealand. Dengan menggunakan agency theory sebagai basis dalam merumuskan hubungan antar variable, mereka menunjukkan bukti bahwa ukuran perusahaan, industri, dan saham yang terdaftar di pasar modal local dan internasional (multiple stock exchange listing) berpengaruh terhadap pengungkapan sosial dan lingkungan. Namun demikian, profitabilitas tidak berpengaruh terhadap pengungkapan sosial dan lingkungan.

f. Deegan dan Gordon (1996) melakukan explorasi praktik pengungkapan lingkungan pada perusahaan di Australia. Dengan menggunakan teori legitimasi mereka membandingkan jumlah pengungkapan lingkungan yang bersifat positive dan negative. Dengan menggunakan Average Industri Environment Sensitivity Index dan Membership Weighted Industri Environmental Sensitivity Index mereka menemukan bahwa perusahaan cenederung mengungkapkan berita positif dan mengurangi berita negatif.

g. Gray et al. (2001) melakukan penelitian pengungkapan sosial di Inggris, dengan menggunakan data base perusahaan Selama delapan tahun, dimana hasilnya menunjukkan bahwa karakteristik perusahaan seperti size, laba, dan jenis industri merupakan faktor yang mempengaruhi pengungkapan sosial dan lingkungan.

h. Amad, Hassan dan Mohammad (2003) melakukan penelitian di lingkup Asia, yang menguji faktor-faktor yang mempengaruhi pengungkapan informasi lingkungan dalam annual report perusahaan di Malaysia. Dengan menggunakan efficient contracting theory, mereka menemukan bahwa hanya variable leverage dan status auditor (Big five) yang mempengaruhi pengungkapan informasi lingkungan.

i. Brammer dan Pavelin (2004) melakukan penelitian pengungkapan sosial dalam perspektif stakeholder theory, dengan menggunakan sample perusahaan besar di Inggris, mereka menemukan bahwa lebih banyak perusahaan yang melakukan pengungkapan lingkungan dibanding yang tidak melakukan pengungkapan. Selain itu, terbukti bahwa ukuran perusahaan dan media exposure merupakan determinan pengungkapan lingkungan. Mereka menyimpulkan bahwa pengungkapan lingkungan digunakan sebagai media untuk memanage persepsi ekstenal stakeholder.

j. Stanwick dan Stanwick (2006) menguji level pengungkapan lingkungan pada perusahaan Jepang. Mereka mengklasifikasikan pengungkapan lingkungan ke dalam tujuh kategori: environmental certification, reporting, processes, strategies, measurement, community efforts dan compliance. Hasilnya menunjukkan bahwa heavily manufacturing industri memiliki pengungkapan yang lebih rendah dalam tujuh kategori tersebut. Sementara consumer product 
industrimemiliki luas pengungkapan yang paling tinggi pada kategori: environmental certification, strategies, dan measurement. Service industri berada di tengah-tengah dalam luas pengungkapan pada kategori: environmental certification, reporting, strategies, measurement, dan compliance. Secara umum ditemukan bahwa pengungkapan dilakukan perusahaan untuk membentuk hubungan sosial yang baik dengan stakeholdernya.

Dari beberapa hasil penelitian di atas, menunjukkan bahwa para peneliti berbeda dalam menggunakan teori yang melandasi penelitian tentang pengungkapan sosial dan lingkungan. Dan nampak bahwa di setiap Negara dan jenis industri cenderung berbeda faktor-faktor penentu pengungkapan sosial dan lingkungan. Misalnya, determinasi pengungkapan sosial dan lingkungan dari ukuran/luas perusahaan oleh Andrew et al. (1989); Patten (1992); Hackston dan Milne (1996); Gray et al. (2001); dan Brammer dan Pavelin (2004). Pengungkapan untuk mendapatkan legitimasi oleh Guthrie dan Parker (1989) dan Patten (1992). Determinasi pengungkapan karena tekanan publik oleh Patten (1991). Pengungkapan untuk memanage persepsi stakeholder oleh Brammer dan Pavelin (2004). Dan pengungkapan yang dipengaruhi oleh jenis industri oleh Gray et al. (2001) dan Stanwick dan Stanwick (2006).

\section{Tantangan Akuntansi Dalam Pengungkapan Sosial dan Lingkungan Untuk Pembangunan Berkelanjutan}

Dalam laporan dari Accounting for Sustainability Groupyang diselenggarakan oleh $H R H$

The Prince of Wales tahun 2006 menunjukkan bahwa di antara tantangan besar yang dihadapi di bidang akuntansi untuk keberlanjutan adalah:

- Kompleksitas dan ketidakpastian subyek, yang dimulai dengan tidak adanya definisi yang jelas dipahami tentang "pembangunan berkelanjutan". Secara umum Brundtland Commission mendefenisikan bahwa pembangunan berkelanjutan sebagai "pembangunan yang memenuhi kebutuhan sekarang tanpa mengorbankan kemampuan generasi mendatang untuk memenuhi kebutuhan mereka sendiri".

- Akuntan memiliki peran penting untuk menentukan keberlanjutan, yang ditunjukkan dengan upaya yang sedang dilakukan oleh badan akuntansi yang mengarah ke profesi yang terlibat dalam isu-isu keberlanjutan.

- kadang-kadang terjadi ketidaknyamanan hubungan antara keberlanjutan dan tujuan utama bisnis, yang secara tradisional dilihat sebagai pertumbuhan modal untuk kepentingan pemegang saham. Meskipun penelitian telah menunjukkan bahwa mengejar praktek bisnis yang berkelanjutan dapat meningkatkan keuntungan jangka panjang, hubungan ini tidak selalu jelas,

67| Page 
dan ada tanda tanya sejauhmana organisasi harus mempertimbangkan faktor yang tidak dapat meningkatkan keuntungan mereka.

- Kesulitan praktis yang dihadapi adalah kenyataan bahwa sistem akuntansi saat ini tidak memfasilitasi masuknya faktor lingkungan dan sosial eksternal untuk operasi organisasi. Neraca terdiri dari aset yang dimiliki oleh organisasi dan kewajiban langsung menimbulkan kewajiban organisasi baik secara hukum yang diharuskan untuk menyelesaikan atau secara sukarela telah berkomitmen untuk membayar. Secara umum, ini tidak termasuk dampak lingkungan dan sosial.

Sementara, Gray (2001) melihat bahwa akuntansi sosial dan lingkungan masih tertanam dalam konvensi, kebiasaan dan peraturan organisasi, dimana menurut Gray bahwa akuntansi sosial dan lingkungan harus tidak lagi tunduk padakehendak politik atau diserahkan pada tindakan sukarela dari perusahaan.

Pandangan Gray (2001) di atas, menunjukkan bahwa belum adanya pelaksanaan akuntansi sosial dan lingkungan secara baik. Kalaupun ada, pelaksanaan tersebut hanya sebagai bentuk ketaatan politik dan juga masih sebatas kesukarelaan dari perusahaan, sehingga belum ada ketegasan pelaksanaannya. Padahal, pihak stakeholder lebih berkepentingan terhadap pengungkapan atas dampak dari aktifitas operasi perusahaan.

\section{Akuntansi Untuk Keberlanjutan Pembangunan}

Idealnya keberlanjutan pembangunan harus menjadi tujuan utama dari semua entitas bisnis, keberlanjutan pembangunan dapat memberikan jaminan eksistensi entitas bisnis dalam jangka panjang. Laporan dari Accounting for Sustainability Group tahun 2006 menyarankan bahwa kita harus mulai menyadari bahwa kita tidak dapat meramalkan hasil secara terus-menerus, dan memaksimisasi laba karena kita belum mampu mengukur efek pada planet ini. Di sinilah peran akuntansi sebagai alat laporan "obyektif" sangat penting. Ada harapan bahwa profesi akuntansi memiliki peran penting untuk menentukan keberlanjutan. Sebagai contoh:

1) The Association of Chartered Certified Accountants (ACCA) dan the Chartered Institute of Management Accountants (CIMA) telah menerbitkan berbagai paper yang mempertimbangkan bagaimana untuk menyertakan ukuran keberlanjutan dalam pelaporan keuangan tradisional, termasuk Full Cost Accounting, laporan Triple Bottom Line dan metodologi Balanced Scorecard. 
2) The Global Reporting Initiative (GRI) adalah sebuah organisasi yang bertujuan untuk membuat laporan tentang ekonomi, kinerja lingkungan dan sosial oleh semua organisasi yang sebanding dan rutin sebagai pelaporan keuangan.

3) The Institute of Chartered Accountants in England and Wales (ICAEW), memiliki sebagian serangkaian publikasi Information for Better Markets yang lebih baik, memberikan panduan kepada para anggotanya jenis layanan yang mungkin diperlukan dalam pelaporan keberlanjutan.

4) The Fédération des Experts Comptables Européens (FEE) telah aktif di bidang akuntansi keberlanjutan sejak tahun 1993 dan telah menghasilkan sejumlah studi dan publikasi pada subjek.

5) The Chartered Institute of Public Finance and Accountancy (CIPFA) telah mempublikasikan Sustainability: A Reporting Framework for the Public Services, model pelaporan keberlanjutan yang dapat diterapkan oleh organisasi sektor publik ketika mempertimbangkan dan pelaporan tentang keberlanjutan organisasi dan tingkat layanan.

6) IFAC, The International Federation of Accountants, telah membentuk dua kelompok kerja keberlanjutan yang telah meluncurkan sebuah program keberlanjutan tiga tahun melalui Professional Accountants in Business Committee, dan telah mengeluarkan pedoman tentang akuntansi manajemen lingkungan dan akuntan profesional secara global dengan sifat profesional yang berinteraksi dalam perdebatan keberlanjutan.

Munculnya berbagai lembaga di atas, menunjukkan belum adanya model pelaporan yang dapat diandalkan untuk mengukur keberlanjutan dan akuntan akan diharapkan untuk memberikan sejumlah besar informasi yang sebelumnya tidak termuat dalam laporan manajemen. Peran akuntan dalam proses ini adalah untuk meningkatkan transparansi kegiatan usaha, khususnya dalam area dampak sosial dan lingkungan.

\section{Kesimpulan}

Tanggung jawab akuntansi dalam mengungkapkan tanggung jawab sosial dan lingkungan perusahaan, terutama perusahaan multi-nasional, telah mengalami peningkatan signifikan dalam dekade terakhir ini. Bersamaan dengan itu, muncul perilaku tidak etis dari kegiatan perusahaan yang berdampak negatif terhadap keberlanjutan pembangunan. Perkembangan ini mendorong akuntansi memiliki posisi strategis untuk memobilisasi informasi sekaligus perubahan dari praktekpraktek bisnis yang kurang etis dan tidak berkelanjutan. Namun, jika peran ini tidak mampu diemban oleh akuntansi, maka kredibilitas pengungkapannya menjadi masalah. 
Para peneliti berbeda dalam menggunakan teori yang melandasi penelitian tentang pengungkapan sosial dan lingkungan. Dan nampak bahwa di setiap Negara dan jenis industri cenderung berbeda faktor-faktor penentu pengungkapan sosial dan lingkungan, misalnya, ukuran/luas perusahaan, untuk mendapatkan legitimasi, karena tekanan publik, untuk mengelola persepsi stakeholder, dan pengungkapan yang dipengaruhi oleh jenis industri.

Berbagai determinasi di atas, sebagai refleksi atas tantangan besar yang dihadapi dalam bidang akuntansi untuk keberlanjutan adalah:

- Kompleksitas dan ketidakpastian subyek, yang dimulai dengan tidak adanya definisi yang jelas dipahami tentang "pembangunan berkelanjutan" sebagai "pembangunan yang memenuhi kebutuhan sekarang tanpa mengorbankan kemampuan generasi mendatang untuk memenuhi kebutuhan mereka sendiri".

- Akuntan memiliki peran penting untuk menentukan keberlanjutan.

- Terjadi ketidaknyaman hubungan antara keberlanjutan dan tujuan utama bisnis.

- Kesulitan praktis yang dihadapi adalah kenyataan bahwa sistem akuntansi saat ini tidak memfasilitasi masuknya faktor lingkungan dan sosial eksternal ke dalam operasi organisasi.

Dengan hadirnya berbagai lembaga yang memberikan panduan bagi akuntansi untuk keberlanjutan pembangunan, namun di sisi lain nampak bahwa belum adanya model pelaporan yang dapat diandalkan untuk mengukur keberlanjutan, sehingga akuntan diharapkan untuk memberikan sejumlah besar informasiyang sebelumnya tidaktermuat dalam laporan manajemen. Peran akuntan dalam proses ini adalah untuk meningkatkan transparansi kegiatan usaha, khususnya dalam area dampak sosial dan lingkungan.

\section{Daftar Referensi}

Burhany, D. Imanina. Akuntansi Sosial Sebagai Alat Bantu Pelaporan Pertanggungjawaban Sosial Perusahaan (Corporate Sosial Responsibility), bahan kuliah Program Magister Sains Akuntansi UNHAS 2011.

Chariri, Anis, 2008. Kritik Sosial atas Pemakaian Teori Dalam Penelitian Pengungkapan Sosial dan Lingkungan, Jurnal Maksi, Vol. 8, No. 2, Agustus 2008; 151-169.

Dey, Colin, 2007.Sosial accounting at Traidcraft plc, A struggle for the meaning of fair trade. Accounting, Auditing \& Accountability Journal, Vol. 20 No. 3, 2007, pp. 423-445, Emerald Group Publishing Limited.

Ebimobowei, Appah, 2011. A Study of Sosial Accounting Disclosures in the Annual Reports of Nigerian Companies. Asian Journal of Business Management3(3): 145-151, 2011, ISSN: 2041-8744 
Gray, Rob, 2001. Thirty years of sosial accounting, reporting and auditing: What (if anything) have we learnt?Business Ethics: A European Review.

Lako, Andreas, 2011. Dekonstruksi CSR \& Reformasi Paradigma Bisnis dan Akuntansi, Penerbit Erlangga.

The Accounting for Sustainability Group, Accounting for Sustainability, Part I: A review of academic literature, A report from the Accounting for Sustainability Group convened by HRH The Prince of Wales, 5 December 2006. 